\title{
EXOGENOUS ENZYMES AND PELLETING INCREASE DIET DIGESTIBILITY OF PIGLETS
}

\author{
(Enzimas exógenas e peletização aumentam a digestibilidade da dieta em leitões)
}

Thiago Augusto Cruz ${ }^{1}$, Aimée Caroline Pereira Stresser ${ }^{1}$, Simone Gisele Oliveira ${ }^{1}$, Leopoldo Malcorra Almeida ${ }^{1}$, Marley Conceição Santos ${ }^{1}$, Ananda Portella Félix ${ }^{1}$

${ }^{1}$ Universidade Federal do Paraná

Corresponding author: sgoliveira@ufpr.br

ABSTRACT: In view of the need to increase food production to meet growing world demand, technologies must be developed to improve the performance of animals for human consumption. In this sense, studies with enzymes inclusion and feed processing have been done in order to improve food efficiency and, consequently, the animal production result. In order to verify the digestibility of complex commercial diets in the pre-initial stage of piglets submitted to the inclusion of an enzymes mixture and or pelletizing, were used 24 castrated male pigs with average age of 35 days and mean weight of $8 \mathrm{~kg}$. The animals were individually housed in metabolism cages and submitted to four treatments: mash diet, mash diet with enzymes, pelleted diet and pelleted diet with addition of the enzyme mixture. After adaptation of the piglets to the diets for seven days, feces were collected for five days for the digestibility trials. The collection method was total collection of feces. There was interaction for digestible energy, crude protein, dry matter and ether extract $(p>0.05)$. Pelleting and inclusion of the enzymatic complex allowed an increase in the coefficient of digestibility in all evaluated parameters $(p<0.05)$. Therefore, the enzyme mixture tested and the pelleting can be used as artifice to increase the digestibility of commercial diets for piglets in the pre-initial phase.

Keywords: Additives; enzyme complex; piglets; processing.

RESUMO: Com a necessidade de aumento de produção de alimentos para atender a crescente demanda mundial, tecnologias devem ser desenvolvidas para melhorar o desempenho dos animais destinados ao consumo humano. Nesse sentido, estudos com inclusão de enzimas e processamento das dietas vêm sendo realizados a fim de melhorar a eficiência alimentar e, por consequência, o resultado zootécnico. Com objetivo de verificar a digestibilidade de dietas comerciais complexas na fase pré-inicial de leitões, submetidas à inclusão de uma mistura de enzimas e ou peletização, foram utilizados 24 suínos machos, castrados, com idade média de 35 dias e peso médio de $8 \mathrm{~kg}$. Os animais foram alojados individualmente em gaiolas de metabolismo e submetidos a quatro tratamentos: ração farelada, ração farelada com adição da mistura de enzimas, ração peletizada e ração peletizada com adição de um complexo enzimático. Após sete dias de adaptação dos leitões as dietas foram coletadas as fezes, por meio da coleta total, por cinco dias para o ensaio de digestibilidade. Houve interação para energia digestível, proteína bruta, matéria seca e extrato etéreo $(p<0,05)$. O processo de peletização e a inclusão do complexo enzimático possibilitaram aumento no coeficiente de digestibilidade em todos os parâmetros avaliados $(p<0,05)$. Dessa forma, a combinação da mistura de enzimas e peletização pode ser utilizada como ferramenta eficaz no aumento da digestibilidade de dietas para leitões na fase préinicial.

Palavras-chave: Complexo enzimático; leitões; nutrição animal; processamento. 


\section{INTRODUCTION}

The digestibility of diets supplied to pigs is dependent on several factors, such as the development of the gastrointestinal tract and the quality and types of raw materials.

Early weaning of piglets, around 21 days of age, takes place before the animal's complete intestinal physiological development. At 35 days of age, although they already have a better development, their digestive capacity is not yet complete, so at this stage the animals are not ready yet to receive a grain and cereal diet. In addition to the limited stomach and small intestine physical capacity, recently weaned piglets have insufficient digestive enzymes secretion, which compromises digestion and adequate absorption of nutrients (Lan et al., 2017).

Contributing negatively to this physiological state, the raw materials used in the nutrition of monogastric animals, such as soybean meal and maize, may present antinutritional factors, such as phytate, non-starch polysaccharides and trypsin inhibitors, reducing nutrients utilization by animals. Considering this scenario, in order to minimize these effects, the inclusion of exogenous enzymes and the feed processing such as pelleting are justified.

Exogenous enzymes hydrolyze specific nutrients fractions, where the endogenous enzymes are not able to act, besides increasing the diet fractions digestibility as starch and proteins, since they are complementary to the enzymes already produced by the animal.

Using a complex of enzymes favors digestion, since they are complementary. Carbohydrases release sugars from carbohydrate complexes, such as xylans, which have the capacity to increase viscosity, so the digesta becomes more susceptible to the actions of other enzymes, both the exogenous as the endogenous, thus observing a synergy.

However, pelleting modifies the nutrients physical characteristics, that make up the diet, thereby facilitating digestion, with increasing temperature and use of pressure and moisture, amylose and amylopectin granules lose their granular characteristics, as well as alter the tertiary structures of proteins, favoring the enzymatic action.

Therefore, the objective of this study was to verify the effect of pelleting and inclusion of a complex of enzymes in the digestibility of dry matter, crude protein, crude fiber, ether extract and digestible energy of a commercial diet for pigs at 35 days of age.

\section{MATERIALS AND METHODS}

\section{Animals}

Twenty-four male piglets, Landrace $x$ Large White, weaned at 21 days and kept in pens until 35 days of age, male, castrated and vaccinated were used.

\section{Location and facilities}

The animals were housed individually in metabolism cages, measuring approximately $4 \mathrm{~m}^{2}$. The cages were made of iron and free of spikes or any other material that could injure the animals. The front was mobile, where it was possible to handle the animals. In addition, they were equipped with a pacifier type drinker and feeder, receiving water and food ad libitum. The cages still had some currents as a way of environmental enrichment, so the animals could express playful behavior. The cages had a vented bottom making possible for the feces and urine to fell into a lower compartment to be collected and to avoid contact with the animals. The cages were housed in an experimental room with ventilation and temperature controlled using heaters, air conditioning and windows, always remaining at $28^{\circ} \mathrm{C}$. 


\section{Experimental diets}

The animals received four diets (Table 1) that meet the nutritional needs for the pre-initial phase (Rostagno et al. 2011): mash diet, mash diet with addition of enzymatic complex, pelleted diet and pelleted diet with addition of the enzyme complex. The nutritional levels calculated with the diets are described in Table 2.

Table 1. Composition of the diets provided to the animals.

\begin{tabular}{|c|c|c|}
\hline Ingredients & Diet without enzyme (g/kg) & Diet with enzyme $(\mathrm{g} / \mathrm{kg})$ \\
\hline Corn & 530.20 & 530.20 \\
\hline Soybran & 260.00 & 260.00 \\
\hline Milk protein & 76.62 & 76.62 \\
\hline Soybean protein concentrate & 36.50 & 36.50 \\
\hline Sugar & 20.00 & 20.00 \\
\hline Dicalcium phosphate & 14.42 & 14.42 \\
\hline Cane yeast & 10.00 & 10.00 \\
\hline Whey protein & 9.05 & 9.05 \\
\hline Red blood cell & 7.00 & 7.00 \\
\hline Methionine $84 \%$ & 5.32 & 5.32 \\
\hline Calcium formate & 5.00 & 5.00 \\
\hline L-tryptophan $10 \%$ & 3.50 & 3.50 \\
\hline Calcitic calcareous & 3.45 & 3.45 \\
\hline $\mathrm{NaCl}$ & 3.40 & 3.40 \\
\hline L-lysine & 3.35 & 3.35 \\
\hline L-Threonine & 2.10 & 2.10 \\
\hline Acidifying $^{1}$ & 2.00 & 2.00 \\
\hline Silicon Dioxide & 2.00 & 1.80 \\
\hline Zinc Oxide & 1.80 & 1.80 \\
\hline Flavoring $^{2}$ & 1.50 & 1.50 \\
\hline Halquinol $10 \%$ & 1.20 & 1.20 \\
\hline Aspartame $10 \%$ & 1.00 & 1.00 \\
\hline Mineral Premix ${ }^{3}$ & 1.00 & 1.00 \\
\hline Vitamin Premix ${ }^{4}$ & 0.30 & 0.30 \\
\hline $\mathrm{BHT}$ & 0.15 & 0.15 \\
\hline Enzymatic Blend & - & 0.20 \\
\hline
\end{tabular}

\footnotetext{
${ }^{1}$ Acetic acid $12 \%$, ammonium formate $17 \%$, formic acid $18 \%$, mono and diglycerides of fatty acid $8 \%$.

${ }^{2}$ Vanilla flavor

${ }^{3}$ Provided per kilogram of diet: Fe, 77.6 mg; Cu, 11.6 mg; Mn, 67.9 mg; Zn, 97.0 mg; I, 0.97 mg; Se, 0.31 mg.

${ }^{4}$ Provided per kilogram of diet: vitamin A, 11,250 Ul; vitamin D3, $2250 \mathrm{UI}$; vitamin E, $22.5 \mathrm{UI}$; vitamin K3, 2.0 $\mathrm{mg}$; vitamin B1, $1.75 \mathrm{mg}$; vitamin B2, $5.0 \mathrm{mg}$; vitamin B6, $1.75 \mathrm{mg}$; vitamin B12, $22.5 \mathrm{mcg}$; niacin, $37.5 \mathrm{mg}$; pantothenic acid, $20.0 \mathrm{mg}$; folic acid, $0.5 \mathrm{mg}$; biotin, $0.125 \mathrm{mg}$.
}

The corn was ground in a hammer mill with a capacity of 150 horsepower in a $2 \mathrm{~mm}$ sieve before undergoing the diets production process.

The pelleting process was carried out in a pellet mill (model 125, Chavantes, São Paulo, Brazil) with capacity of 10 tons/hour. In the conditioning process, a pressure of $1 \mathrm{~kg} / \mathrm{cm}^{2}$ of steam with a constant temperature of $70^{\circ} \mathrm{C}$ was used. The diet passed through a matrix with a $1.5 \mathrm{~mm}$ hole and a thickness of $1 \mathrm{~cm}$. The ambient temperature at the time of the process was $15^{\circ} \mathrm{C}$.

The enzyme complex used was supplied by Lumis Biotech Pvt. LTD. Located in Mumbai, India. The code 
IUBMB (Enzyme Nomenclature) is EC 3.2.1.8 and CAS 9025-57-4 (number with a unique record in the Chemical
Abstracts Service database, a division of the Chemical American Society).

Table 2. Nutritional levels calculated and analyzed of the diets supplied to the animals.

\begin{tabular}{lc}
\hline \multicolumn{1}{c}{ Item } & Diet \\
\hline Analyzed (\%) & 89.94 \\
Dry matter & 21.60 \\
Crude protein & 4.43 \\
Ether extract & 2.95 \\
Crude fiber & 0.86 \\
Calcium & \\
Calculated (\%) & 1.33 \\
Digestible Lysine & 0.75 \\
Digestible Methionine & 0.99 \\
Digestible Methionine + Cysteine & 0.84 \\
Digestible Threonine & 0.24 \\
Digestible Tryptophan & 0,45 \\
Digestible Phosphorus & 0.21 \\
Sodium (mg/kg) & 1500 \\
Zinc (mg/kg) & 3374.97 \\
Metabolisable energy (kcal/kg) &
\end{tabular}

The enzyme complex contained Cellulase $(800,000 \mathrm{U} / \mathrm{g}), \quad$ Amylase $(120,000 \mathrm{U} / \mathrm{g})$, Xylanase $(20,000 \mathrm{U} / \mathrm{g})$, $\beta$-glucanase $(7,500 \mathrm{U} / \mathrm{g})$, Mannanase $(250 \mathrm{U} / \mathrm{g})$, Protease $(1,400 \mathrm{U} / \mathrm{g})$ and Phytase $(1,000 \mathrm{U} / \mathrm{g})$. They have a thermostability up to $90^{\circ} \mathrm{C}$ and the trade name is Precizyon $X$. The enzymes were added topically, that is, the nutritional matrix was not considered.

\section{Data collect}

The animals underwent a seven days adaptation consuming the diets and later were weighed at the first day of the experiment, presenting an average weight of $8 \mathrm{~kg}$. The diets were provided ad libitum for five days. The food offered and dietary leftovers were weighed every morning to calculate consumption.

The total feces was collected every morning and conditioned in individual plastic bags, and frozen at $-5^{\circ} \mathrm{C}$. At the end of the five days, the samples were thawed, homogenized and dried in a forced ventilation oven at $55^{\circ} \mathrm{C}$ for 72 hours. Samples of feces and feeds were ground to $1 \mathrm{~mm}$ and analyzed to determine dry matter (DM), crude protein $(\mathrm{CP})$, ether extract (EE) and crude fiber (CF) (AOAC, 1995). The gross energy (GE) was measured in a bomb calorimeter (Parr Instrument Co., Model 1261, Moline, IL, USA). The apparent digestibility coefficient (ADC) was calculated using the equations:

$A D C=[(g$ ingested nutrient $-g$ excreted nutrient)/ $\mathrm{g}$ ingested nutrient]

Statistical analysis

The design was completely randomized, the 24 animals were individually distributed in metabolism cages, each animal as an experimental unit. There were four treatments with six replicates in factorial arrangement $2 \times 2$ : two physical types of diet, pelleted and mash, with and without addition of the enzymatic complex.

The data were submitted to the Shapiro-Wilk test for normality. Once the normality of the data was confirmed, a variance analysis was performed at $5 \%$ 
of significance, the interaction was verified and a Tukey test was performed at $5 \%$ of significance, by the SAS statistical analysis program (Version 8, SAS Institute Inc., Cary, NC, USA).

\section{RESULTS AND DISCUSSION}

There was interaction between the pelleting and the enzyme complex for ADC of DM, CP, EE and digestible energy $(D E ; p<0.05)$ and there was no interaction for ADCCF (Table 3).

Table 3. Mean of the apparent digestibility coefficients of dry matter (DM), crude protein (CP), ether extract (EE), crude fiber (CF) and digestible energy (DE).

\begin{tabular}{|c|c|c|c|c|c|c|c|c|}
\hline & \multicolumn{2}{|c|}{ Pelleted } & \multicolumn{2}{|c|}{ Mash } & \multirow[b]{2}{*}{ SEM $^{1}$} & \multicolumn{3}{|c|}{ P-value ${ }^{2}$} \\
\hline & $\begin{array}{c}\text { With } \\
\text { enzyme }\end{array}$ & $\begin{array}{l}\text { Without } \\
\text { Enzyme }\end{array}$ & $\begin{array}{c}\text { With } \\
\text { Enzyme }\end{array}$ & $\begin{array}{l}\text { Without } \\
\text { Enzyme }\end{array}$ & & $P$ & $E$ & $P \times E$ \\
\hline & \multicolumn{8}{|c|}{ Apparent digestibility coefficients (\%) } \\
\hline DM & $86.16 a$ & $83.74 b$ & $85.15 b$ & $83.92 b$ & 0.619 & 0.353 & 0.189 & $<0.001$ \\
\hline $\mathrm{CP}$ & $85.58 a$ & $79.94 c$ & $82.90 b$ & $80.50 c$ & 0.742 & 0.057 & 0.006 & $<0.001$ \\
\hline EE & $84.45 a$ & $75.66 b$ & $66.33 c$ & $61.42 d$ & 1.115 & $<0.001$ & 0.024 & $<0.001$ \\
\hline CF & $63.52 a$ & $63.66 a$ & $49.54 b$ & $62.43 a$ & 4.078 & 0.033 & 0.065 & 0.700 \\
\hline DE (kcal) & $4122.3 a$ & $4023.4 b$ & $3962.9 b$ & $3892.6 c$ & 20.78 & $<0.001$ & 0.034 & $<0.001$ \\
\hline
\end{tabular}

1 SEM $=$ Standard error of the mean.

$2 \mathrm{P}=$ Pelleting, $\mathrm{E}=$ Enzymes, $\mathrm{P} \times \mathrm{E}=$ Pelleting $\times$ Enzymes interaction.

In relation to $D E$, the use of the enzyme complex added to the pelleting provided higher digestibility $(p<0,05)$, when compared to the use of the pelleting and the enzyme alone, suggesting that the use of temperature and humidity facilitated the exogenous enzymes in the substrate.

The increase of the DE is related to the action of the temperature and humidity used in the pelleting process, this process causes expansion of the starch granules, with that, the amylose solubilizes and the amylopectin chains break easily. With the starch gelatinization, the energy digestibility is increased (Ma et al., 2019).

This result agrees with authors (Yang et al., 2017; Rojas et al., 2016), who explained that the pelleting favors the enzymatic action and increase the digestible energy but differs on carbohydrates and crude protein digestibility. In the present study, the pelleting process favored the exogenous enzymes, which could express its potential more effectively because of the substratum structures modification, also the enzymes were thermoresistant because they were not inactivated in the process.

In the same way, ADCEE was higher $(p<0,05)$ for the treatment that contained pelleted diet and with enzymes addition. This increase in digestibility is explained by the greater exposure of lipids to endogenous lipase. In addition to the physical action described, the enzymes facilitated the digestion of other lipid-bound fractions, such as carbohydrates and proteins, increasing the bioavailability of this fraction (Adams and Jensen, 1984).

Also for ADCCP, pelleting and enzymes caused a synergistic effect. Although the enzyme mixture in the mash diet increased ADCCP $(p<0,05)$ compared to the mash and pelleted diets without enzymes, in the pelleted diet, the enzymatic mixture provided a $(p<0,05)$ additive effect. Although the diet contained proteins of high biological value such as milk proteins and yeasts, and therefore, pelleting alone did not increase $(p>0,05)$ the ADCCP, it facilitated the action of the enzymes in the other less bioavailable proteins, probably, changing the tertiary structures (Moran, 1987; Dozier, 2001). 
According to Salazar-Villanea (2017), there should be an improvement in the digestibility of $\mathrm{CP}$ with pelleting, since the increase in temperature and pressure, during the processing of soybean meal, contributes to protein digestibility due to the denaturation of proteins that exposes new sites to the enzymatic attack, improving the digestibility of the amino acids.

Though, in this study there was no positive interference of the pelleting in the ADCCP $(p>0,05)$, however, a tendency was observed $(p=0,057)$, agreeing with Yang et al. (2017) that in studies with pigs consuming pelleted and meal diets, found similar results for $\mathrm{CP}$, that is, pelleted ration tend to present better ADCCP $(p<0,05)$ in relation to mash form diet. In the case of the present study, this may have occurred due to the fact that the diet used is of the complex type, that is, it contains several protein sources, such as sugarcane yeast and milk proteins, because they are more digestible sources when compared to corn and soybean meal, increased the digestibility of the total CP of the diet, therefore, it was not possible to observe difference of the pelleted diet when compared to the meal.

It was expected that there would be an increase in fiber digestibility due to processing, however, the analytical method of CF is not ideal due to the high degree of error. This is justified because the fibers pass through an acidic hydrolysis and later basic hydrolysis, with that, important fractions like the hemicelluloses could have been lost and, therefore, not being representative.

\section{The ADCCF presented} inconclusive data. This is probably because pigs have the ability, although small due to age, to ferment fibers in the large intestine. In this case, the possible individual fermentative action of each animal did not generate assertive data.
However, the inclusion of the enzyme complex increased the digestibility of DE, EE and CP (Table 3).

The increase in DE is associated with the release of fractions of the carbohydrates whose endogenous enzymes are not able to hydrolyze. The inclusion of the enzyme complex probably enabled the release of sugars such as xylans and $\beta$-glucans, which in principle are not available due to the endogenous enzymatic inefficiency of non-ruminant animals. These data are in accordance with Liu et al. (2019) and Li et al. (2015) who also observed increase in DE with carbohydrate enzymes inclusion.

As for $\mathrm{CP}$, the increase in digestibility can be linked to two factors; the first one is that the enzyme complex presents proteases that allow gains in corn and soybean meal diets digestibility, since they potentiate the use of poorly available proteins and proteins with antinutritional factor (Ndazigaruye et al., 2019).

According to Rezende et al. (2012) proteases in pigs diets aid the endogenous enzymes in the digestion, or they can still digest nutrients that are not available at first. In a similar way, Ndazigaruye et al. (2019) observed a positive action of the inclusion of proteases in diets based on corn and soybean, on digestibility and nitrogen excretion.

The second important factor in increasing the digestibility of CP is linked to the carbohydrases, since they can decrease the viscosity of the digesta. Because of this higher viscosity, nutrients such as lipids, starch and proteins become less accessible and available to endogenous enzymes. Thus, the diffusion rate of substrates and digestive enzymes is reduced, which impedes their interactions on the surface of the intestinal mucosa leading to impairment of digestion and 
absorption of nutrients (Kölln et al., 2017).

\section{CONCLUSIONS}

The enzymatic complex used containing xylanase, amylase, mannanase, $\beta$-glucanase, protease and phytase, and the diet pelleting at $70^{\circ} \mathrm{C}$, showed positive action and can be used as tools to increase nutrients digestibility for pigs at 35 days of age, as well as synergy in the use of these technologies.

\section{INFORMATIVE NOTES}

The study was approved by the Committee on Ethics in the Use of Animals of the Sector of Agricultural Sciences of the Federal University of Paraná, n. 021/2015.

\section{REFERENCES}

ADAMS, K.L.; JENSEN, A.H. Comparative utilization of in-seed fats and the respective extracted fats by the young pig. Journal Animal Science, v.59, n.6, p.1557-1566, 1984.

AOAC.Official Methods of Analysis, 16th ed. Association of Official Analytical Chemists, 1995.

DOZIER, W.A. Cost-effective pallet quality for meat birds. Feed Management, v.52, n.2, p.1-3, 2001.

KÖLLN, M.; WEIß, H.; HANKEL, J. et al. Effects of a carbohydrase complex added in different inclusion rates in feeds for broilers on growth performance, digesta viscosity and foot pad health. Journal of Animal Physiology and Animal Nutrition, v.101, n.S1, p.105-109, 2017.

LAN, R.; LI, T.; KIM, I. Effects of xylanase supplementation on growth performance, nutrient digestibility, blood parameters, fecal microbiota, fecal score and fecal noxious gas emission of weaning pigs fed corn-soybean meal-based diet. Animal Science Journal, v.88, n.9, p.1398-1405, 2017.

LI, Y.; ZHANG, A.R.; LUO, H.F. et al. In vitro and in vivo digestibility of corn starch for weaned pigs: Effects of amylose: amylopectin ratio, extrusion, storage duration, and enzyme supplementation. Journal of Animal Science, v.93, n.7, p.3512-3520, 2015.

LIU, S.; MA, C.; LIU, L. et al. $\beta-$ xylosidase and $\beta$-mannosidase in combination improved growth performance and altered microbial profiles in weanling pigs fed a cornsoybean meal-based diet. AsianAustralasian Journal of Animal Sciences, v.32, n.11, p.1734-1744, 2019.

MA, D.; LI, J.; HUANG, C. et al. Determination of the energy contents and nutrient digestibility of corn, waxy corn and steam-flaked corn fed to growing pigs. Asian-Australasian Journal of Animal Sciences, v.32, n.10, p.1573-1579, 2019.

MORAN, E.T. Pelleting affects feed and its consumption. World Poultry, v.5, n.1, p.30-31, 1987.

NDAZIGARUYE, G.; KIM, D.; KANG, C. et al.. Effects of low-protein diets and exogenous protease on growth performance, carcass traits, intestinal morphology, cecal volatile fatty acids and serum parameters in broilers. Animals, v.9, n.5, p.226, 2019.

REZENDE, I.M.B.L.; DUTRA, W.M.J.; REZENDE, F.M. et al. Digestibility of the cottonseed meal with or without addition of protease and phytase enzymes in swine diet. Acta Scientiarum. Animal Science, v.34, n.3, p.259-265, 2012.

ROJAS, O.J.; VINYETA, E.; STEIN, H.H. Effects of pelleting, extrusion, or extrusion and pelleting on energy and 
nutrient digestibility in diets containing different levels of fiber and fed to growing pigs. Journal of Animal Science, v.94, n.5, p.1951-1960, 2016.

ROSTAGNO, H.S.; ALBINO, L.F.T.; DONZELE, J.L. et al. Tabelas brasileiras para aves e suínos: composição de alimentos e exigências nutricionais. 3 . ed. Viçosa: UFV; 2011.

SALAZAR-VILLANEA, S.; BRUININX, E.M.A.M.; GRUPPEN, H. et al. Pelleting and extrusion can ameliorate negative effects of toasting of rapeseed meal on protein digestibility in growing pigs. Animal, v.12, n.5, p.950-958, 2018.

YANG, Y.Y.; FAN, Y.F.; CAO, Y.H. et al. Effects of exogenous phytase and xylanase, individually or in combination, and pelleting on nutrient digestibility, available energy content of wheat and performance of growing pigs fed wheatbased diets. Asian-Australasian Journal of Animal Sciences, v.30, n.1, p.57-63, 2017. 